www.jmscr.igmpublication.org Impact Factor 5.244

Index Copernicus Value: 83.27

ISSN (e)-2347-176x ISSN (p) 2455-0450

crossref DOI: _https://dx.doi.org/10.18535/jmscr/v4i12.116

Journal Of Medical Science And Clinical Research

\title{
Knowledge, Attitude and Practice in Relation to Stroke: Comparative Study between Hypertensive and Non-Hypertensive Patients Attending a Tertiary Care Centre in Gorakhpur, Uttar Pradesh, India
}

\author{
Authors \\ Venkatesh $\mathbf{U}^{1}$, Srivastava $\mathbf{D K}^{2}$ \\ ${ }^{1}$ Final year Resident, ${ }^{2}$ Professor, \\ Department of Community Medicine, BRD Medical College, Gorakhpur, UP, India \\ Email-venkatesh2007mbbs@gmail.com
}

\begin{abstract}
Introduction - It is not possible to reduce the stroke burden, without the awareness in public and concerned attitude and practice towards the same. It is vital to analyse public awareness about present knowledge, attitude and practices (KAP) to prevent mortality-morbidity of stroke particularly in high risk cases.

Objective - To study the knowledge, attitude and practice in relation to stroke among hypertensive and nonhypertensive patients attending a tertiary care centre $O P D$.

Methodology - Cross-sectional study was conducted at Medicine OPD of BRD Medical College in the month of November 2016. Consecutive Sampling was used to enrol the patients in two groups (Hypertensive and Non-hypertensive patients). Sample size was calculated using G power 3.1.9.2. Individual score were calculated for Knowledge, Attitude and Practice section and analysed using T- test.

Results - The mean difference in Knowledge score of HTN group was $1.99 \pm 0.86$ and $1.91 \pm 0.96$ in Non HTN group patients $(p=0.54)$. The Attitude score of HTN group was $19.22 \pm 2.34$ and $18.79 \pm 2.11$ in Non HTN group $(p=0.15)$. Whereas the Practice score in HTN group was $6.5 \pm 2.1$ and $6.96 \pm 2.2$ in Non HTN group patients $(p=0.13)$.

Conclusion - Insignificant difference in Knowledge, Attitude and Practice scores of HTN and Non-HTN group. We found $66.7 \%$ of patients attending tertiary care centre are good in knowledge, knowledge, $73.8 \%$ are having positive attitude, $62.9 \%$ having good practice in relation to stroke.

Keywords - Stroke, Awareness, Knowledge, Attitude, Practice, Hypertension.
\end{abstract}

\section{INTRODUCTION}

Stroke is considered as one of the major cause of death and disability globally. It creates economical and psychological complexities for patients and their families. The victims of stroke are still a major burden on the healthcare system. But still, in developing countries the incidence of stoke is seen increasing in contrast to the developed countries. ${ }^{[1]}$
In India the burden of stroke has been raising over preceding few decades ${ }^{[2]}$ when compared to developed countries where it is noted to be stable or decreasing ${ }^{[3]}$. At present, it is estimated to be approximately 1.8 million Indians out of total population i.e. 1.2 billion suffer from stoke every year and annually about one third of them die whereas other one third suffers from disability that are permanent. These statistics emphasize the 
necessity with which the phenomenon of stoke is needed to be studied in India with the goal to reduce the massive burden of stroke that the country is facing. ${ }^{[4]}$

It is not possible to reduce the stroke burden, without the awareness in public and concerned attitude and practice towards the same. In such instance, it is also important to know that therapeutic opportunities are limited in stroke. Additionally, there is lake of awareness and concern about the timely treatment of hypertension and adaptation of proper lifestyle that may help to reduce the incidence of stroke and morbidity among the stroke survivors in long run. ${ }^{[5]}$

KAP studies have been chiefly undertaken in developed countries all across the continents, assessing hospital based patients or related setups, or community dwellers through house to house survey ${ }^{[6],[7],[8],[9],[10],[11],[12],[13]}$. The studies conducted in Asia have also been mostly undertaken in the developed countries such as, Hong Kong, South Korea. ${ }^{[14],[15]}$. Studies that are conducted in developing countries have been restricted to very few countries like Brazil, Oman, Iran, India, Pakistan across the continent $^{[16],[17],[18],[19]}$.

It is vital to analyse public awareness about present knowledge, attitude and practices (KAP) to prevent mortality-morbidity of stroke particularly in high risk cases. In case of insufficient knowledge among the mass, governmental and non-governmental efforts to empower the mass with adequate knowledge, practice and the right attitude may help stretch this objective.

\section{OBJECTIVE}

To study the knowledge, attitude and practice in relation to stroke among hypertensive and nonhypertensive patients attending a tertiary care centre OPD

\section{METHODOLOGY}

Cross-sectional study was conducted at Medicine OPD of BRD Medical College in the month of November 2016. Consecutive Sampling was used to enrol the patients in two groups (Hypertensive and Non-hypertensive patients). After a written informed consent, using standardised questionnaire with aextensive range of responses were read to the participants. Questionnaire were divided in to four section with a pre-defined scoring criteria. Demographic profile of patient including epidemiological determinants which can affect the patient knowledge, attitude and practice in relation to stroke were recorded to compare between the two groups. Known case of hypertensive on Medication were enrolled in hypertensive group and Normal blood pressure patients with no history of CVD were enrolled in Non-hypertensive group. Sample size was calculated using $\mathrm{G}$ power 3.1.9.2, with two tailed alpha error of $5 \%$, power of study $95 \%$, effect size of $0.5,1: 1$ allocation ratio of two groups, the calculated sample size was 210 (105 in each group). Individual score were calculated for Knowledge, Attitude and Practice section and analysed using $\mathrm{T}$ - test. Epidemiological determinants were compared using chi square test.

\section{RESULTS}

The participants from the hypertensive (HTN) group were age-matched with the participants of the non-hypertensive (Non-HTN) group (mean \pm standard deviation: $47.5 \pm 14.03$ years in the HTN group; $47.9 \pm 14.19$ years in the Non-HTN group; $\mathrm{P}=0.649$ ) but were not matched in terms of gender. There were 35 female respondents $(33.3 \%)$ in the HTN Group compared to 31 females $(29.5 \%)$ in the Non HTN Group ( $\mathrm{P}=$ $0.55)$. There was a no significant difference in the number of years of formal education between respondents from the two groups $(\mathrm{P}=0.28)$. Table 1 . 
Table 1 . Demographic Profile of Hypertensive and Non- Hypertensive patients

\begin{tabular}{|c|c|c|c|}
\hline Characteristic & $\begin{array}{l}\text { Hypertensive } \\
\text { N }(\%)\end{array}$ & $\begin{array}{c}\text { Non -Hypertensive } \\
\text { N }(\%)\end{array}$ & $\begin{array}{c}\text { Statistical } \\
\text { Significance* }\end{array}$ \\
\hline $\begin{array}{l}\text { Gender } \\
\text { Male } \\
\text { Female }\end{array}$ & $\begin{array}{l}70(66.7) \\
35(33.3)\end{array}$ & $\begin{array}{l}74(70.5) \\
31(29.5)\end{array}$ & $\begin{array}{c}\chi 2-0.35, \mathrm{df}-1 \\
p-0.55\end{array}$ \\
\hline $\begin{array}{l}\text { Age Category } \\
30-50 \mathrm{yrs} \\
51-70 \mathrm{yrs} \\
\text { Above } 70 \mathrm{yrs}\end{array}$ & $\begin{array}{l}48(45.7) \\
44(41.9) \\
13(12.4)\end{array}$ & $\begin{array}{l}40(38.1) \\
46(43.8) \\
19(18.1)\end{array}$ & $\begin{array}{c}\chi^{2}-1.89, \mathrm{df}-2 \\
\mathrm{p}-0.38\end{array}$ \\
\hline $\begin{array}{l}\text { Locality } \\
\text { Rural } \\
\text { Urban }\end{array}$ & $\begin{array}{l}60(57.1) \\
45(42.9)\end{array}$ & $\begin{array}{l}52(49.5) \\
53(50.5)\end{array}$ & $\begin{array}{c}\chi^{2}-1.22, \mathrm{df}-1 \\
\mathrm{p}-0.26\end{array}$ \\
\hline $\begin{array}{l}\text { Marital status } \\
\text { In union } \\
\text { Not in union }\end{array}$ & $\begin{array}{l}94(89.5) \\
11(10.5)\end{array}$ & $\begin{array}{l}88(83.8) \\
17(16.2)\end{array}$ & $\begin{array}{c}\chi^{2}-1.48, \mathrm{df}-1, \\
\mathrm{p}-0.22\end{array}$ \\
\hline $\begin{array}{l}\text { Socioeconomic status } \\
\text { Upper class } \\
\text { Upper middle } \\
\text { Lower middle } \\
\text { Upper lower } \\
\text { Lower }\end{array}$ & $\begin{array}{c}1(1.0) \\
10(9.5) \\
59(56.2) \\
14(13.3) \\
21(20.0)\end{array}$ & $\begin{array}{l}2(1.9) \\
18(17.1) \\
58(55.2) \\
14(13.3) \\
13(12.4)\end{array}$ & 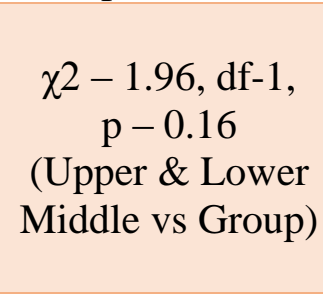 \\
\hline $\begin{array}{l}\text { Smoking habits } \\
\text { Non smoker } \\
\text { Smoker }\end{array}$ & $\begin{array}{l}75(71.4) \\
30(28.6)\end{array}$ & $\begin{array}{l}72(68.6) \\
33(31.4)\end{array}$ & $\begin{array}{c}\chi^{2}-0.20, \mathrm{df}-1 \\
\mathrm{p}-0.65\end{array}$ \\
\hline $\begin{array}{l}\text { Alcoholism } \\
\text { Habitual } \\
\text { Social } \\
\text { Never }\end{array}$ & $\begin{array}{c}5(4.8) \\
6(5.7) \\
94(89.5)\end{array}$ & $\begin{array}{c}8(7.6) \\
13(12.4) \\
84(80.0)\end{array}$ & $\begin{array}{c}\chi 2-3.83, \mathrm{df}-2 \\
\mathrm{p}-0.14\end{array}$ \\
\hline $\begin{array}{l}\text { History of diabetes } \\
\text { Yes } \\
\text { No }\end{array}$ & $\begin{array}{l}32(30.5) \\
73(69.5)\end{array}$ & $\begin{array}{l}31(29.5) \\
74(70.5)\end{array}$ & $\begin{array}{c}\chi^{2}-0.02, \mathrm{df}-1 \\
\mathrm{p}-0.88\end{array}$ \\
\hline $\begin{array}{l}\text { Educational status } \\
\text { illiterate } \\
\text { Primary level Education } \\
\text { Secondary level / higher } \\
\text { level }\end{array}$ & $\begin{array}{l}33(31.4) \\
35(33.3) \\
37(35.2)\end{array}$ & $\begin{array}{l}32(30.5) \\
26(24.8) \\
47(44.8)\end{array}$ & $\begin{array}{c}\chi^{2}-2.53, \mathrm{df}-1 \\
p-0.28\end{array}$ \\
\hline $\begin{array}{l}\text { Family history CVD } \\
\text { Yes } \\
\text { No }\end{array}$ & $\begin{array}{l}47(44.8) \\
58(55.2)\end{array}$ & $\begin{array}{l}40(38.1) \\
65(61.9)\end{array}$ & $\begin{array}{c}\chi^{2}-0.96, \mathrm{df}-1 \\
\mathrm{p}-0.37\end{array}$ \\
\hline
\end{tabular}

In knowledge section patients knowledge regarding basic awareness including prevention, risk factor and Consequence of stroke were recorded. Almost $80 \%$ of people in both group are aware that hypertension as a risk factor for occurrence of stroke, other risk factors are registered low in both group. In HTN group 18.6
$\%$ people are consider family history of CVD as a risk factor while in Non- HTN group it is $21.6 \%$ (Figure 1 A). $72.45 \%$ in HTN group and $65.7 \%$ in Non-HTN group are aware that paralysis of limb or body is the consequence of Stroke followed by headache and confusion (45.7\% in HTN \& $65.7 \%$ Non-HTN). (Figure 1B). 
Figure 1. Distribution of patient's response on Knowledge about Risk factor (A) and Consequences (B) of Stroke(Both are Multiple Response Questions)

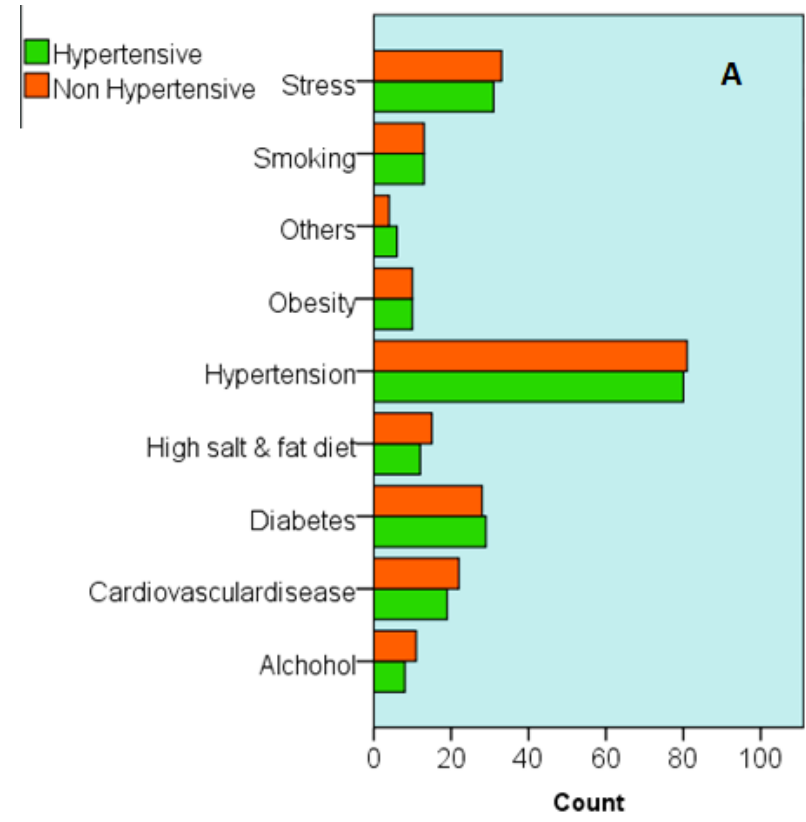

Regarding awareness on prevention of occurrence of stroke $73.3 \%$ in HTN group \& $71.4 \%$ in NonHTN group believed that medication as a way of prevention. $42.9 \%$ in HTN group $\& 37.1 \%$ in NonHTN group were aware that regular physical

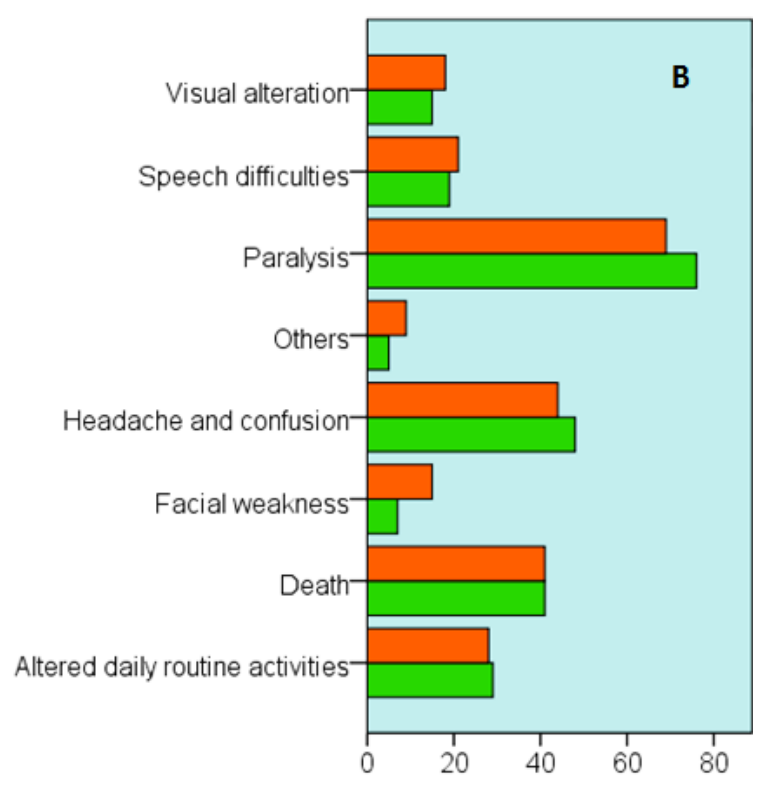

exercise can prevent the episode of stroke (Figure2 ). Responses to other measures of prevention such as weight reduction, quitting smoking and alcohol were low.

Figure 2. Bar chart showing distribution of preventive measures awareness responses of stroke

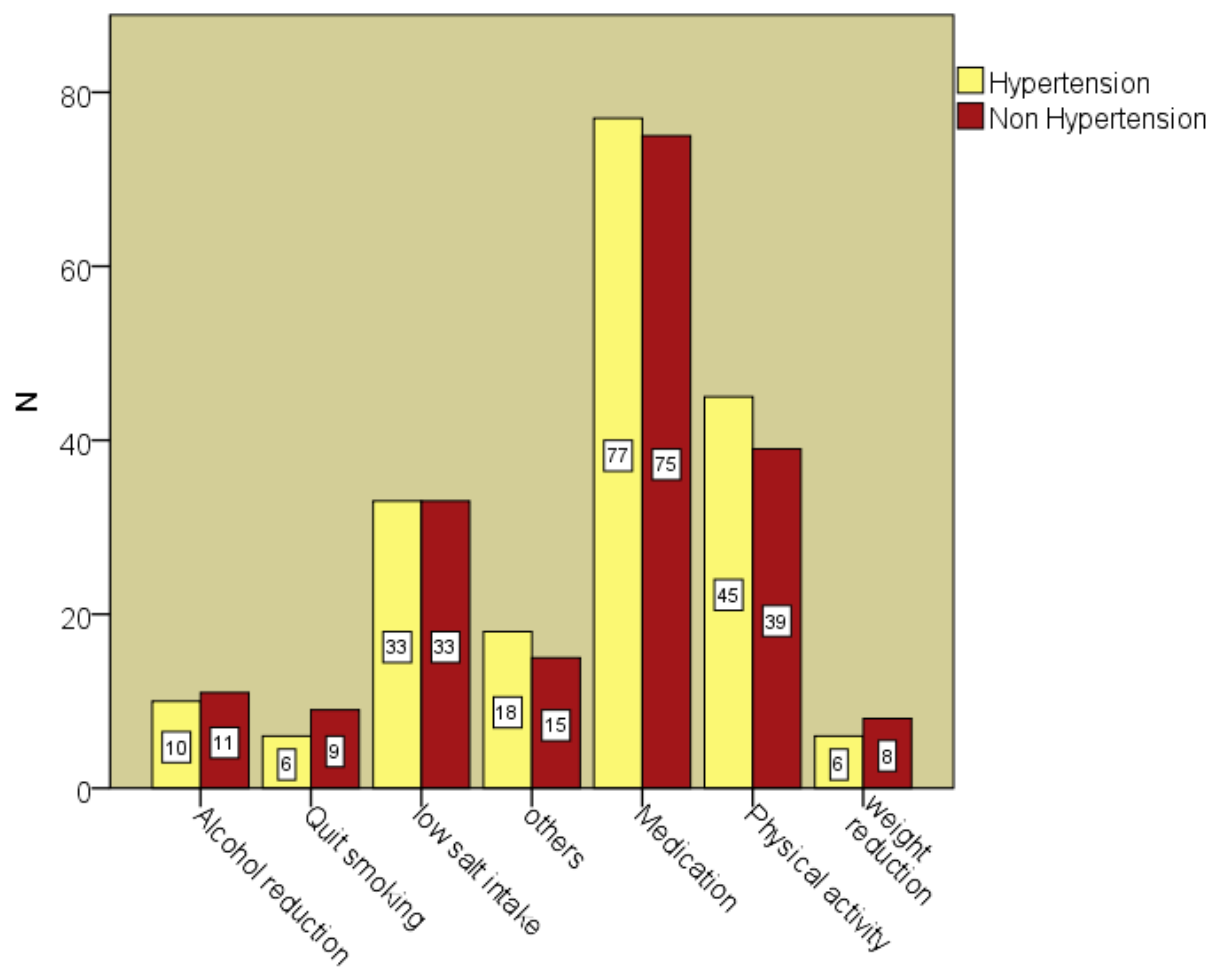




\section{JMSCR Vol||04||Issue||12||Page 15014-15021||December}

Table-2: Table showing patients attitude responses in relation to stroke using Likert scale

\begin{tabular}{|c|c|c|}
\hline Characteristic & $\begin{array}{l}\text { Hypertensive } \\
\text { N }(\%)\end{array}$ & $\begin{array}{c}\text { Non-Hypertensive } \\
\mathbf{N}(\%)\end{array}$ \\
\hline $\begin{array}{l}\text { High BP only risk factor of stroke } \\
\text { Strongly agree } \\
\text { Agree } \\
\text { Don't know } \\
\text { Disagree } \\
\text { Strongly disagree }\end{array}$ & $\begin{array}{c}5(4.8) \\
53(60) \\
6(5.7) \\
31(29.5) \\
0(0.0)\end{array}$ & $\begin{aligned} 7 & (6.7) \\
68 & (64.8) \\
6 & (5.7) \\
24 & (22.9) \\
0 & (0.0)\end{aligned}$ \\
\hline $\begin{array}{l}\text { Stroke only happens in elderly people } \\
\text { Strongly agree } \\
\text { Agree } \\
\text { Don't know } \\
\text { Disagree } \\
\text { Strongly disagree }\end{array}$ & $\begin{array}{c}12(11.4) \\
54(51.4) \\
4(3.8) \\
25(23.8) \\
10(9.5)\end{array}$ & $\begin{aligned} 12 & (11.4) \\
55 & (52.4) \\
4 & (3.8) \\
22 & (21.0) \\
12 & (11.4)\end{aligned}$ \\
\hline $\begin{array}{l}\text { Regular strenuous exercise can cause stroke } \\
\text { Strongly agree } \\
\text { Agree } \\
\text { Don't know } \\
\text { Disagree } \\
\text { Strongly disagree }\end{array}$ & $\begin{array}{c}13(12.4) \\
44(41.9) \\
20(19.0) \\
21(20.0) \\
7(6.7)\end{array}$ & $\begin{array}{c}19(18.1) \\
33(31.4) \\
31(29.5) \\
17(16.2) \\
5(4.8)\end{array}$ \\
\hline $\begin{array}{l}\text { Regular strenuous physical exercise can cause } \\
\text { stroke } \\
\text { Strongly agree } \\
\text { Agree } \\
\text { Don't know } \\
\text { Disagree } \\
\text { Strongly disagree }\end{array}$ & $\begin{array}{c}34(32.4) \\
66(62.9) \\
3(2.9) \\
2(1.9) \\
0(0.0)\end{array}$ & $\begin{array}{c}33(31.4) \\
67(63.8) \\
4(3.8) \\
1(1.0) \\
0(0.0)\end{array}$ \\
\hline $\begin{array}{l}\text { Stroke patient can become paralysed for life } \\
\text { Strongly agree } \\
\text { Agree } \\
\text { Don't know } \\
\text { Disagree } \\
\text { Strongly disagree }\end{array}$ & $\begin{aligned} 4 & (3.8) \\
54 & (51.4) \\
5 & (4.8) \\
39 & (37.1) \\
3 & (2.9)\end{aligned}$ & $\begin{aligned} 5 & (4.8) \\
39 & (37.1) \\
7 & (6.7) \\
52 & (49.5) \\
2 & (1.9)\end{aligned}$ \\
\hline $\begin{array}{l}\text { Fear of having a stroke concerns you } \\
\text { Strongly agree } \\
\text { Agree } \\
\text { Don't know } \\
\text { Disagree } \\
\text { Strongly disagree }\end{array}$ & $\begin{aligned} 10 & (9.5) \\
80 & (76.2) \\
3 & (2.9) \\
12 & (11.4) \\
0 & (0.0)\end{aligned}$ & $\begin{aligned} 12 & (11.4) \\
77 & (73.3) \\
3 & (2.9) \\
13 & (12.4) \\
0 & (0.0)\end{aligned}$ \\
\hline
\end{tabular}

$60 \%$ of HTN group and $58.1 \%$ of Non HTN group patient visit nearby hospital for the routine checkup. Intake of fruits and vegetables regularly once in a day in $37.1 \%$ of HTN group and $52.4 \%$ of Non HTN group. While $54.3 \%$ of HTN group $49.5 \%$ of Non HTN group have practice of consuming fatty/oily food. $47.6 \%$ of HTN group and $38.1 \%$ of Non HTN group patients never spend time for any physical activity other than routine work. (Table-3) 


\section{JMSCR Vol||04||Issue||12||Page 15014-15021||December}

Table-3: Table showing patient's practices in order to prevent occurrence of stroke among two groups

\begin{tabular}{|c|c|c|}
\hline Characteristic & $\begin{array}{l}\text { Hypertensive } \\
\mathbf{N}(\%)\end{array}$ & $\begin{array}{l}\text { Non -Hypertensive } \\
\mathbf{N}(\%)\end{array}$ \\
\hline $\begin{array}{l}\text { Do you take the prescribed medications regularly } \\
\text { Yes } \\
\text { No } \\
\text { Sometimes }\end{array}$ & $\begin{array}{l}83(79.0) \\
3(2.9) \\
19(18.1)\end{array}$ & $\begin{array}{l}86(81.9) \\
2(1.9) \\
17(16.2)\end{array}$ \\
\hline $\begin{array}{l}\text { Where do you regularly go for routine follow up } \\
\text { This health centre } \\
\text { Nearby hospital } \\
\text { Nearby primary health centre }\end{array}$ & $\begin{array}{l}1(1.0) \\
63(60.0) \\
41(39.0)\end{array}$ & $\begin{array}{l}1(1.0) \\
61(58.1) \\
43(41.0)\end{array}$ \\
\hline $\begin{array}{l}\text { How often do you consume fruits and vegetables } \\
\text { Never } \\
1 \text { time a day } \\
2 \text { times a day }\end{array}$ & $\begin{array}{l}39(37.1) \\
59(56.2) \\
7(6.7)\end{array}$ & $\begin{array}{l}35(33.3) \\
55(52.4) \\
15(14.3)\end{array}$ \\
\hline $\begin{array}{l}\text { How often do you consume fatty/oily food } \\
\text { Never } \\
1 \text { time a day } \\
2 \text { times a day } \\
>3 \text { times a day }\end{array}$ & $\begin{array}{l}26(24.8) \\
21(20.0) \\
57(54.3) \\
1(1.0)\end{array}$ & $\begin{array}{l}23(21.9) \\
27(25.7) \\
52(49.5) \\
3(2.9)\end{array}$ \\
\hline $\begin{array}{l}\text { How often do u do physical activity } \\
\text { 1-3 times a week } \\
\text { 3-5 times a week } \\
\text { 5-7 times a week } \\
\text { Never }\end{array}$ & $\begin{array}{l}8(7.6) \\
15(14.3) \\
32(30.5) \\
50(47.6)\end{array}$ & $\begin{array}{l}13(12.4) \\
17(16.2) \\
35(33.3) \\
40(38.1)\end{array}$ \\
\hline
\end{tabular}

The mean difference in Knowledge score of HTN group was $1.99 \pm 0.86$ and $1.91 \pm 0.96$ in Non HTN group patients $(\mathrm{p}=0.54)$. The Attitude score of HTN group was $19.22 \pm 2.34$ and $18.79 \pm 2.11$ in Non HTN group $(\mathrm{p}=0.15)$. Whereas the Practice score in HTN group was $6.5 \pm 2.1$ and Table-4: Mean difference between HTN and Non HTN patients Knowledge, Attitude, and Practice score

\begin{tabular}{|c|c|c|c|}
\hline & HTN Group & $\begin{array}{l}\text { Non-HTN } \\
\text { Group }\end{array}$ & Statistical significance \\
\hline & $\operatorname{Mean}(\mathrm{SD})$ & $\operatorname{Mean}(\mathrm{SD})$ & \\
\hline Knowledge $(\mathbf{N}=105)$ & $1.99(0.86)$ & $1.91(0.96)$ & $\mathrm{t}=.605, \mathrm{df}=208, \mathrm{p}=0.546$ \\
\hline Attitude ( $N=105)$ & $19.22(2.34)$ & $18.79(2.11)$ & $\mathrm{t}=1.422, \mathrm{df}=208, \mathrm{p}=0.156$ \\
\hline Practice $(N=105)$ & $6.50(2.18)$ & $6.96(2.20)$ & $\mathrm{t}=-1.511, \mathrm{df}=208, \mathrm{p}=0.132$ \\
\hline
\end{tabular}

*Independent sample t-test

\section{DISCUSSION}

We found insignificant difference in Knowledge, Attitude and Practice scores of HTN and NonHTN group. The results indicate that in general, study participants from both stroke-affected and non-affected families were aware of the basic meanings of the term "stroke" and its association with paralysis. The knowledge regarding stroke
$6.96 \pm 2.2$ in Non HTN group patients $(p=0.13)$. The difference between these two group's Knowledge, Attitude, and Practice scores were analysed using independent sample $\mathrm{T}$ test and found insignificant in all three domain. (Table-4) 
Table 5: Classification of KAP Scores of all patients attending tertiary health care centre

\begin{tabular}{|l|l|}
\hline Knowledge & $N(\%)$ \\
$\begin{array}{l}\text { Poor }(>\text { Mean }+ \text { SD) } \\
\text { Average (Mean } \pm \text { SD) } \\
\text { Good }(>\text { Mean }+ \text { SD) }\end{array}$ & $11(5.2)$ \\
\hline $\begin{array}{l}\text { Attitude } \\
\text { Bad attitude }\left(<50^{\text {th }} \text { percentile }\right)\end{array}$ & $59(28.1)$ \\
Good attitude $\left(\geq 50^{\text {th }}\right.$ percentile $)$ & $140(66.7)$ \\
\hline $\begin{array}{l}\text { Practice } \\
\text { Good practice }\left(<50^{\text {th }} \text { percentile }\right)\end{array}$ & $78(26.2)$ \\
Bad Practice $\left(\geq 50^{\text {th }}\right.$ percentile $)$ & $132(62.1)$ \\
\hline
\end{tabular}

We found $66.7 \%$ of patients attending tertiary care centre are good in knowledge, knowledge, $73.8 \%$ are having positive attitude, $62.9 \%$ having good practice in relation to stroke. Our study is limited by the fact that it was cross-sectional, used closeended questions, and was confined to a fairly limited geographic area. This might have limited the responses regarding knowledge and attitudes to stroke omitting some of the respondents' responses.

\section{ACKNOWLEDGEMENTS}

We would like to acknowledge Undergraduates students posted in Department of Community Medicine of BRDMC, Gorakhpur for their help in data collection during their clinical posting

\section{REFERENCES}

1. Suwanwela NC, Poungvarin N. Stroke burden and stroke care system in Asia. Neurology India. 2016 Feb 1;64(7):46.

2. Kaul S. Stroke in India: are we different from the world. Pak J Neurol Sci. 2007 Jul;2(3):158-64.

3. Feigin VL, Lawes CM, Bennett DA, Barker-Collo SL, Parag V. Worldwide stroke incidence and early case fatality reported in 56 population-based studies: a systematic review. The Lancet Neurology. 2009 Apr 30;8(4):355-69.

4. Dalal PM, Bhattacharjee M. Stroke epidemic in India: hypertension-stroke control programme is urgently needed. JAPI. 2007 Oct 5;55:689-91.
5. Das SK, Banerjee TK. Stroke Indian Scenario. Circulation. 2008 Dec 16;118(25):2719-24.

6. Neau JP, Ingrand P, Godeneche G. Awareness within the French population concerning stroke signs, symptoms, and risk factors. Clinical neurology and neurosurgery. 2009 Oct 31;111(8):659-64.

7. Yoon SS, Heller RF, Levi C, Wiggers J, Fitzgerald PE. Knowledge of stroke risk factors, warning symptoms, and treatment among an Australian urban population. Stroke. 2001 Aug 1;32(8):1926-30.

8. Schneider AT, Pancioli AM, Khoury JC, Rademacher E, Tuchfarber A, Miller R, Woo D, Kissela B, Broderick JP. Trends in community knowledge of the warning signs and risk factors for stroke. Jama. 2003 Jan 15;289(3):343-6.

9. Pancioli AM, Broderick J, Kothari R, Brott $\mathrm{T}$, Tuchfarber A, Miller R, Khoury J, Jauch E. Public perception of stroke warning signs and knowledge of potential risk factors. Jama. 1998 Apr 22;279(16):1288-92.

10. Weltermann BM, Homann J, Rogalewski A, Brach S, Voss S, Ringelstein EB. Stroke knowledge among stroke support group members. Stroke. 2000 Jun 1;31(6):1230-3.

11. Kim JS, Yoon SS. Perspectives of Stroke in Persons Living in Seoul, South Korea A Survey of 1000 Subjects. Stroke. 1997 Jun $1 ; 28(6): 1165-9$. 
12. Cheung RF, Li LW, Mak W, Tsang K, Lauder I, Chan K, Fong GY. Knowledge of stroke in Hong Kong Chinese. Cerebrovascular Diseases. 1999 Feb 17;9(2):119-23.

13. Sloma A, Backlund LG, Strender LE, Skånér Y. Knowledge of stroke risk factors among primary care patients with previous stroke or TIA: A questionnaire study. BMC Fam Pract 2010;11:47.

14. Campos-Sousa RN, Soares VY, Almeida KJ, Carvalho LI, Jacobina KS, Netto A, Escórcio A, Macêdo ED, Veloso LA. Knowledge of stroke among a Brazilian urban population. Arquivos de neuropsiquiatria. 2007 Sep;65(3A):587-91.

15. BorhaniHaghighi A, Karimi AA, Amiri A, Ghaffarpasand F. Knowledge and attitude towards stroke risk factors, warning symptoms and treatment in an Iranian population. Medical Principles and Practice. 2010 Sep 28;19(6):468-72.

16. Al Shafaee MA, Ganguly SS, Al Asmi AR. Perception of stroke and knowledge of potential risk factors among Omani patients at increased risk for stroke. BMC neurology. 2006 Oct 20;6(1):1.

17. Aly Z, Abbas K, Kazim SF, Taj F, Aziz F, Irfan A, Sheikh R, Shakir M, Javed SM, Fatmi Z. Awareness of stroke risk factors, signs and treatment in a Pakistani population. Journal of the Pakistan Medical Association. 2009;59(7):495-9.

18. Pandian JD, Jaison A, Deepak SS, Kalra G, Shamsher S, Lincoln DJ, Abraham G. Public awareness of warning symptoms, risk factors, and treatment of stroke in northwest India. Stroke. 2005 Mar 1;36(3):644-8.

19. Das K, Mondal GP, Dutta AK, Mukherjee B, Mukherjee BB. Awareness of warning symptoms and risk factors of stroke in the general population and in survivors stroke. Journal of clinical neuroscience. 2007 Jan $31 ; 14(1): 12-6$.
20. Pandian JD, Jaison A, Deepak SS, Kalra G, Shamsher S, Lincoln DJ, et al. Public awareness of warning symptoms, risk factors, and treatment of stroke in northwest India. Stroke 2005;36:644-8

21. Das K, Mondal GP, Dutta AK, Mukherjee B, Mukherjee BB. Awareness of warning symptoms and risk factors of stroke in the general population and in survivors stroke. J ClinNeurosci 2007;14:12-6 